\title{
Erratum to: Impact of graphite admixture on electrical properties of alkali-activated slag mortars
}

\author{
Ivo Kusak ${ }^{1}$, Miroslav Lunak ${ }^{1}$ and Pavel Rovnanik ${ }^{2}$ \\ ${ }^{1}$ Institute of Physics, Faculty of Civil Engineering, Brno University of Technology, Veveři 95, 60200 Brno, Czech Republic \\ ${ }^{2}$ Institute of Chemistry, Faculty of Civil Engineering, Brno University of Technology, Veveři 95, 60200 Brno, Czech Republic
}

Original article:

MATEC Web of Conferences 107, 00035 (2017), DOI: 10.1051/matecconf/201710700035

Acknowledgments at the end of the article should be replaced by the following text:

This outcome has been achieved with the financial support of the Czech Science Foundation, project GA CR 16-00567S and the Ministry of Education, Youth and Sports of the Czech Republic for the "National Sustainability Programme I" (project No. LO1408 AdMaS UP). 